Article

\title{
Distribution and Habitat Selection of Free-Ranging European Bison (Bison bonasus L.) in a Mosaic Landscape-A Lithuanian Case
}

\author{
Vitas Marozas ${ }^{1, *}$, Artūras Kibiša ${ }^{1}$, Gediminas Brazaitis ${ }^{1}$, Kalev Jõgiste ${ }^{2,3}$, \\ Kastytis Šimkevičius ${ }^{1}$ and Edmundas Bartkevičius ${ }^{1}$ \\ 1 Faculty of Forest Science and Ecology, Vytautas Magnus University, Studentu str. 11, LT-53361 Akademija, \\ Kauno r., Lithuania; arturas.kibisa@vdu.lt (A.K.); gediminas.brazaitis@vdu.lt (G.B.); \\ kastytis.simkevicius@vdu.lt (K.Š.); edmundas.bartkevicius@vdu.lt (E.B.) \\ 2 Institute of Forestry and Rural Engineering, Estonian University of Life Sciences, Fr. R. Kreutzwaldi 5, \\ 51006 Tartu, Estonia; kalev.jogiste@emu.ee \\ 3 Department of Forest Resources, University of Minnesota, 115 Green Hall, 1530 Cleveland Avenue North, \\ St Paul, MN 55108, USA \\ * Correspondence: vitas.marozas@vdu.lt; Tel.: +370-37-752-224
}

Received: 14 March 2019; Accepted: 16 April 2019; Published: 19 April 2019

\begin{abstract}
In Lithuania, free-ranging European bison live sedentarily in the fragmented landscape of the central part of the country. The aim of this study was to analyze the distribution and habitat selection of European bison in a semi-isolated territory. Free-ranging European bison living sedentarily have formed six groups in the mosaic landscape of central Lithuania. A herd of 34 individuals of European bison entered into a new semi-isolated territory in 2016. During the snow-free season, we tracked the movements of the herd by fitting a global positioning system (GPS) collar to the leading cow. To evaluate the home range and habitat selection, we used ArcGIS software, Jacobs' index, and chi-square testing to verify significant differences between proportions. The home range of European bison was largest in spring, decreased in summer, and increased again in autumn; this was associated with feeding and the food supply in agricultural lands. European bison spent more time in the forest, especially during the daytime, due to disturbance, but in summer time and at night, the bison did not avoid agricultural land. In the forests, European bison preferred clear-cut, small-leaved deciduous (aspen, grey alder) forests of middle and mature age, but they avoided broad-leaved deciduous (ash), coniferous, and young forests. The increased number of European bison caused damage to agricultural crops and increased conflict with farmers.
\end{abstract}

Keywords: agricultural land; clear-cut; crops; forest; home-range

\section{Introduction}

European bison (Bison bonasus Linnaeus, 1758) have spread throughout almost all of Europe, historically. Habitat conversion to agriculture, forest management intensification, and hunting caused the extinction in the wild of European bison [1]. The last wild European bison population in the Białowieża forest, Poland, became extinct in 1919. After World War I, European bison survived only in a few European zoological parks. The reintroduction of European bison into natural ecosystems started in the Białowieża forest in 1952 [2], and since then, free-ranging herds have formed in Poland, Lithuania, Belarus, Ukraine, Russia, and Kyrgyzstan [1,3,4]. About $60 \%$ of animals living free are distributed within the historical range of the species. The largest bison population currently exists in the Białowieża forest $[1,5]$. The total population of free-ranging European bison now stands at less than 2000. In addition, about 1400 individuals live in captivity [1]. 
The increasing human population and intensive agricultural activities have caused a gradual decrease in forest coverage and greater landscape fragmentation [6]. The development of road and rail networks has increasingly fragmented and degraded natural habitats. Animal populations are isolated from each other, impairing their genetic variability and, consequently, their survival. Despite the tenet that European bison are generally considered a forest species, and several studies have suggested that they are able to live in fragmented landscapes $[1,7,8]$, they have a grass-rich habitat specialist background [9]. Higher bison densities in fragmented forest ecosystems result in their expansion to agricultural habitats [10]. The introduction of large animals affects the pre-existing ecological equilibrium and can cause damage, mainly to crops [11-15].

The European bison, the largest mammal in Europe, is listed by the International Union for Conservation of Nature (IUCN) as a species that is vulnerable to extinction (Red List of Threatened Species). The European bison population consists of small and isolated herds whose long-term survival depends on the formation of larger and connected populations. The "Bison rewilding plan 2014-2024" [16] describes a vision of achieving viable populations of free-ranging bison, as one of the flagship species, restored across Europe and integrated into Europe's landscapes alongside human populations. The listed threats include insufficient habitats, small population size, low acceptance, and others [16].

In Lithuania, the European bison conservation plan was approved in 2014 and revised in 2017 [17]. This plan prioritizes the establishment of captivity in more remote regions over the support of free-ranging European bison in already occupied territories, due to high densities of humans and their agricultural activities. Despite the new captivity territories being established and some European bison individuals being caught from the wild, the size of the free-ranging population has been increasing by $15 \%-25 \%$ annually over the last 4 years (Figure 1 ).

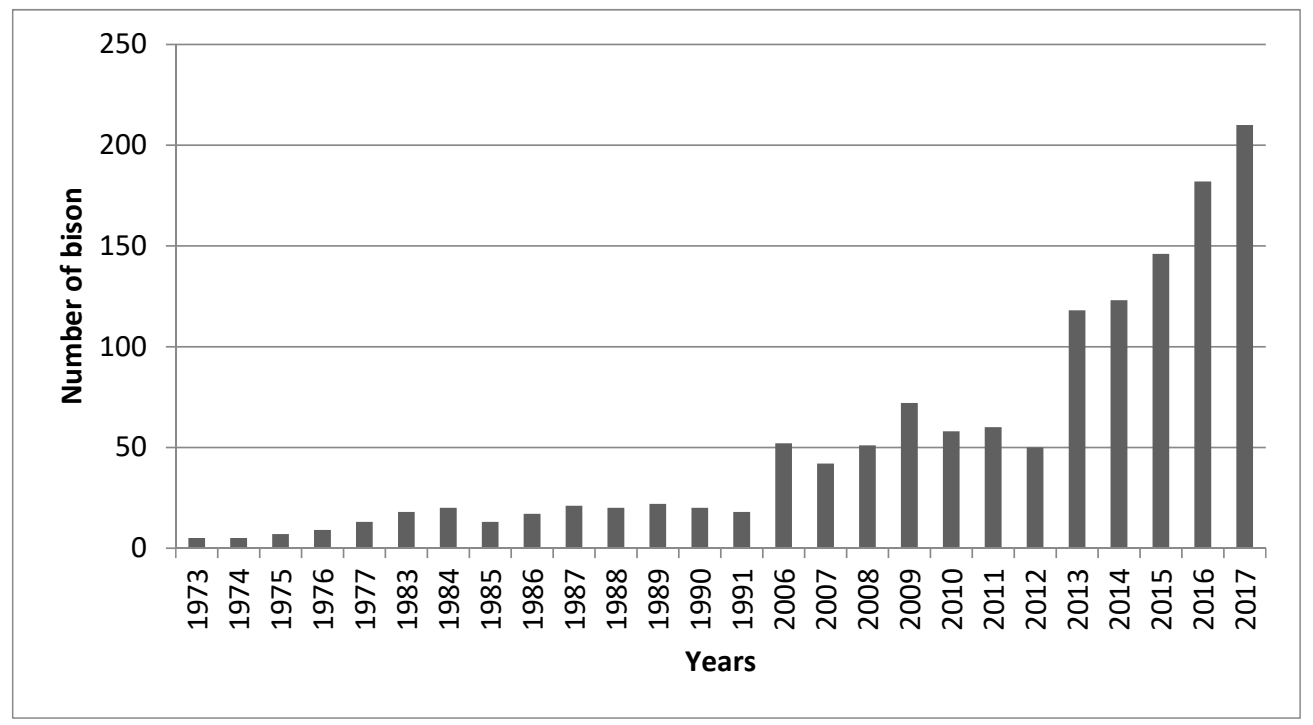

Figure 1. Change in the population of free-ranging European bison in Lithuania (source: Ministry of Environment of the Republic of Lithuania).

The success of the European bison rewilding relies on effective introduction and acclimatization of the species in new areas as well as its later ability to spread and occupy suitable neighboring territories [16]. Gaps in our knowledge about habitat use and preferences in human-dominated landscape have been the main obstacles for the conservation of the European bison [1]. Most studies on this species have analyzed populations established decades before in the primary introduction areas, whereas studies of the areas that this species came to occupy themselves by spreading are lacking. For successful European bison rewilding, there is a need for regional case studies on their natural spread over different regions, within an intensive agricultural landscape with lots of infrastructure 
elements (i.e., fenced highways, roads, railways, etc.) and scattered forest fragments. Knowledge of their movement and habitat use in a human-dominated landscape is essential for further successful reintroductions of the European bison [18]. We therefore need to understand the movement patterns and habitat use of species if we wish to effectively predict and limit the impact of environmental changes on populations $[19,20]$. The formation and dispersal of European bison female herds is an event that is rarely observed within populations. Every such case is worth studying, as it is important for the population's well-being.

This study focused on a newly formed European bison herd that naturally split from the maternal group and occupied a semi-isolated fragmented area previously free of this species. We analyzed the home range and habitat selection of this herd during the snow-free season in the newly colonized territory. We hypothesized that the European bison home range's use of forest and agriculture land would change during the vegetation season.

\section{Materials and Methods}

\subsection{Study Area}

In Lithuania, European bison occupy a territory of 57 thousand hectares in the central part of the country. The total population is split into several groups. The herd of 34 individuals of European bison studied herein entered into a new semi-isolated territory with a total area of 1172 ha. Forests comprised 436 ha, while intensively used agricultural fields comprised the remaining 736 ha of the territory. The territory was partly isolated by highway E67 on one side, a railway on another side, and a water dam and urban areas on the third side (Figure 2). The bison herd entered this territory in the beginning of March. During the tracking period, the herd did not cross the "borders" of this territory due to the intensively used highway, the railway, and the dam, and they did not get too close to villages.

In the study territory, moist fertile soils prevailed. Deciduous and mixed forests dominated by birch (Betula pendula Roth, B. pubescens Ehrh.), black and grey alder (Alnus glutinosa (L.) Gaertn., A. incana (L.) Moench), and ash (Fraxinus excessior L.) are spread widely across the territory. A coniferous species-Norway spruce (Picea abies (L.) H. Karst.) —-was present in the stands but dominated only in 7 percent of the total forest area. In the agricultural land, crops of cereals (spring and winter wheats), corns, and grasses dominated.

\subsection{Data Sampling}

Data on European bison numbers, their distribution, and compensation payments for their damage to agricultural crops were obtained from the Ministry of Environment, Republic of Lithuania. Data on the area of crops damaged by European bison in the Kedainiai district were obtained from the Municipality of Kèdainiai, Lithuania.

In the snow-free period lasting from early spring to late autumn, European bison form structured herds and depend on natural food resources in the forest [21,22]. During the snow-free season of 2016 (from March to November), we tracked the movements of the herd by fitting a global positioning system (GPS) collar equipped with a global system for mobile communication (GSM) module to the leading cow. We used the collar model "Ecotone Modul BISON GPS-GSM-UHF". The collar was set to record GPS locations at 8-hour intervals. We obtained a total of 1389 relocations of the herd.

We retrieved information about forest habitats from the standwise forest inventory database of the Lithuanian Forest Service. Using ArcGis software, we calculated the proportions of agricultural and forest land in the semi-isolated territory. For forest land, we calculated habitat proportions for site type, dominating forest stand tree species, and stand age. We distinguished four site types according to a moisture gradient: Dry, moist, wet, and peat. The prevailing stands were grouped according to the dominating tree species (ash, birch, black alder, grey alder, and aspen) and according to groups of dominant tree species (coniferous, broad-leaved, and small-leaved trees). We grouped 
forest stands according to age into the following groups: clear-cut, 10-20, 30-40, 50-60, 70-80, 90-100, and $>100$ years old.

For the agricultural land, we identified the crop type (cereal, corn, grasses, abandoned land) visually and estimated the area using ArcGis software.

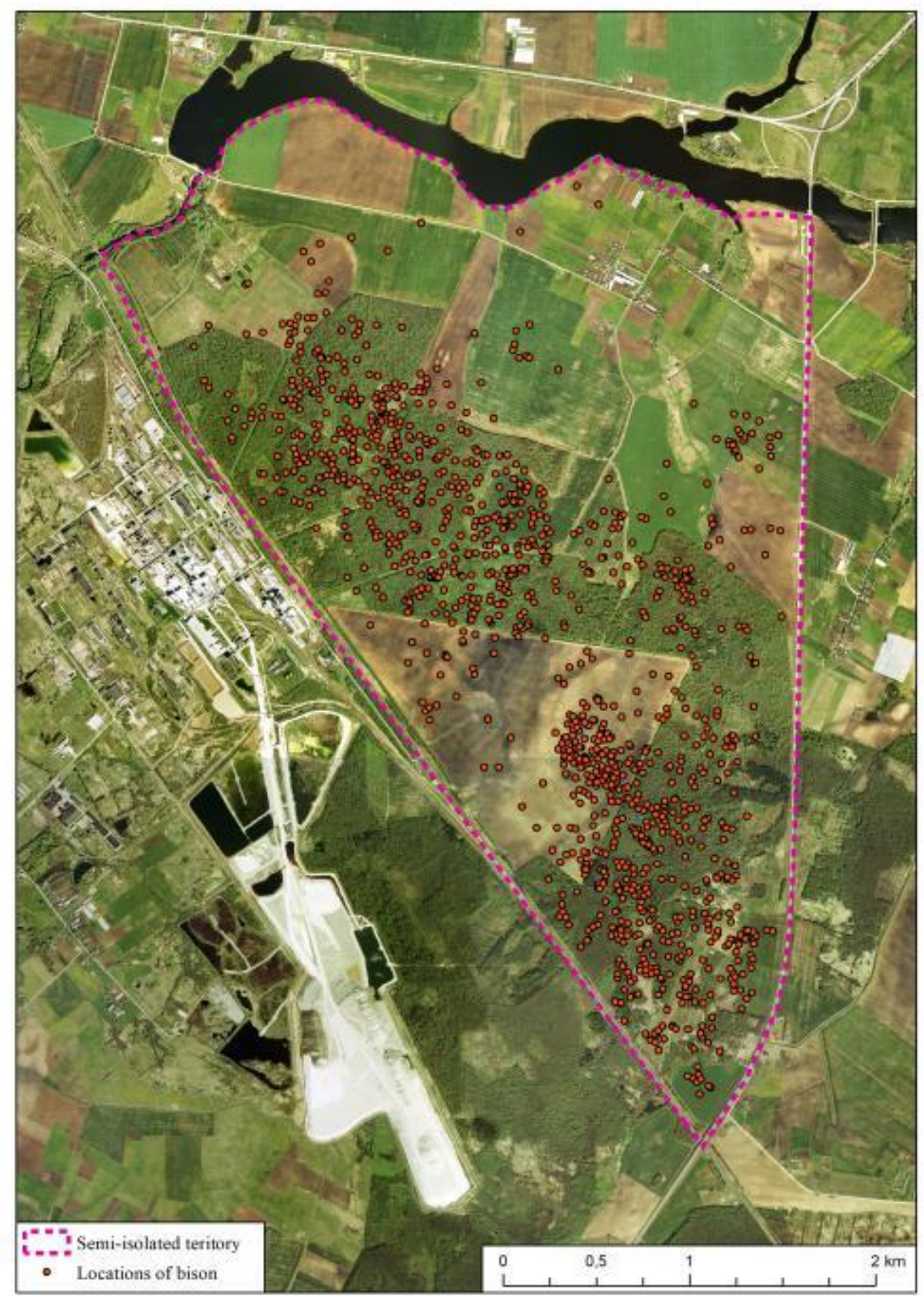

Figure 2. The semi-isolated territory of the studied European bison herd during the snow-free season in 2016.

\subsection{Data Analyses}

We used ArcGIS software to calculate the average home range of the bison herd for each month using the method of the 95\% minimum convex polygon [23]. Habitat selection of the herd was determined using the obtained GPS locations and the detailed habitat information. We compared the habitat found at each location derived from the GPS collars with the overall semi-isolated territory and determined the habitat selection. 
To evaluate habitat selection, we used Jacobs' index [24]:

$$
\mathrm{D}=(\mathrm{r}-\mathrm{p}) /(\mathrm{r}+\mathrm{p}-2 \mathrm{rp})
$$

where $\mathrm{r}$ is a fraction of a habitat among habitats used by bison and $\mathrm{p}$ is a fraction of a habitat in a semi-isolated territory. $\mathrm{D}$ values range from -1 for maximum avoidance to +1 for maximum positive selection. We set up the critical value of Jacobs' index at \pm 0.2 . We used the chi-square test to verify significant differences between the proportion of the availability of a habitat based on the vegetation cover area and the habitat selection.

\section{Results}

\subsection{Distribution of and Damage by Free-Ranging European Bison}

In Lithuania, the European bison was reintroduced in 1969. An enclosure for bison was built in the central part of the country (Figure 3). Bison were breeding successfully; the first young individuals were born in the forest enclosure and were released to the wild just near the enclosure in 1971. After two years, the first free-ranging herd was established in Pašiliai, near the breeding station [20].

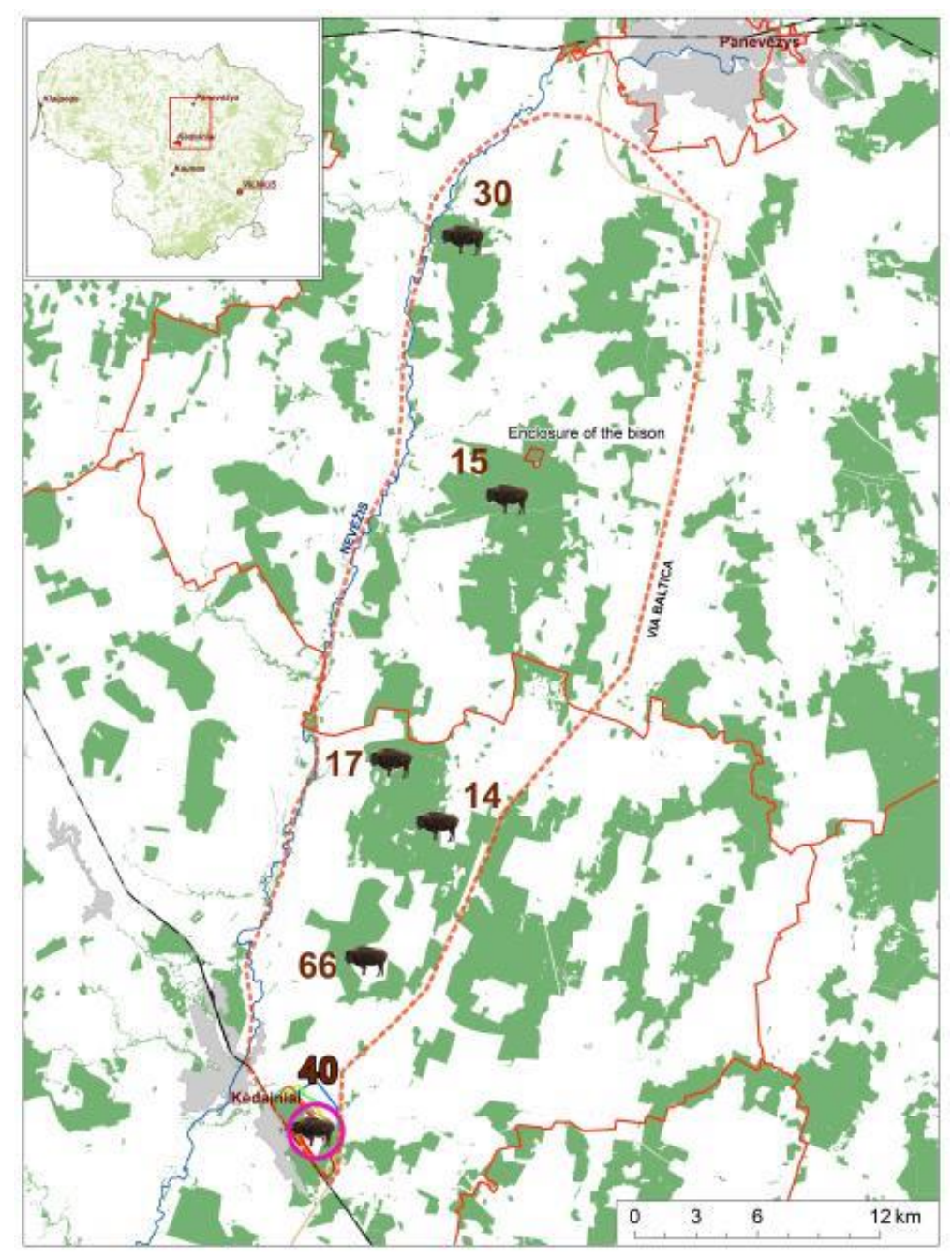

Figure 3. Distribution of free-ranging European bison in Lithuania, 2016 (numbers show sizes of herds; dotted lines show the range of European bison).

Primarily, a population of 20-30 sedentary individuals formed in the Panevėžys region. The population consisted of separate herds of males and females with juveniles. For a long time, 
there have been over 30 animals due to the self-regulating mechanism of the optimal herd structure. Almost every year, individuals were seen wandering; however, most of them were lost due to accidents, poaching, and other causes [7]. The size of the population has been increasing since 2003. An extreme increase has been observed since 2013 in the Panevėžys and Kèdainiai regions. Now free-ranged European bison live sedentarily in a territory of 57 thousand ha in the central part of Lithuania, where mosaic agricultural land and forest patches prevail. The current population of the European bison exceeds 200 individuals (Figure 1). The population is split into six groups of 14-66 individuals each (Figure 3).

The growth of the European bison population in Lithuania has caused increasing damage to agricultural crops. For example, the largest area of winter rape and winter wheat was damaged by European bison in the Kèdainiai district in 2016-2017 (Figure 4).

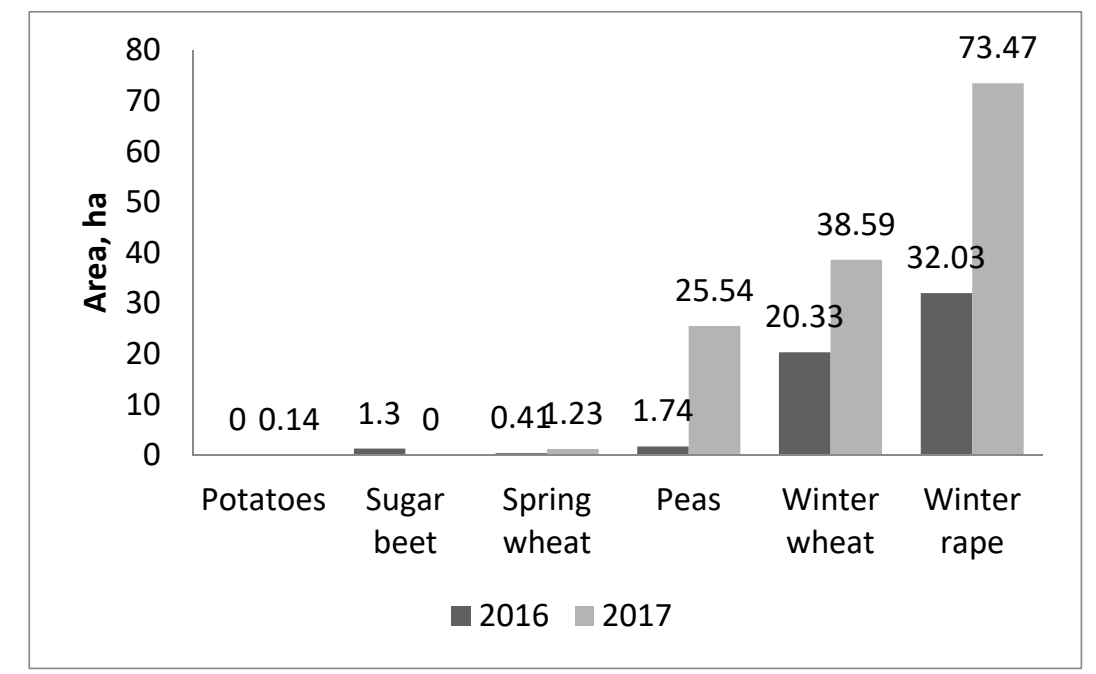

Figure 4. Area of crops damaged by European bison in the Kèdainiai district in 2016-2017 (source: Municipality of Kèdainiai, Lithuania).

The damage compensation to farmers has recently increased up to 259 thousand euros per year (Figure 5).

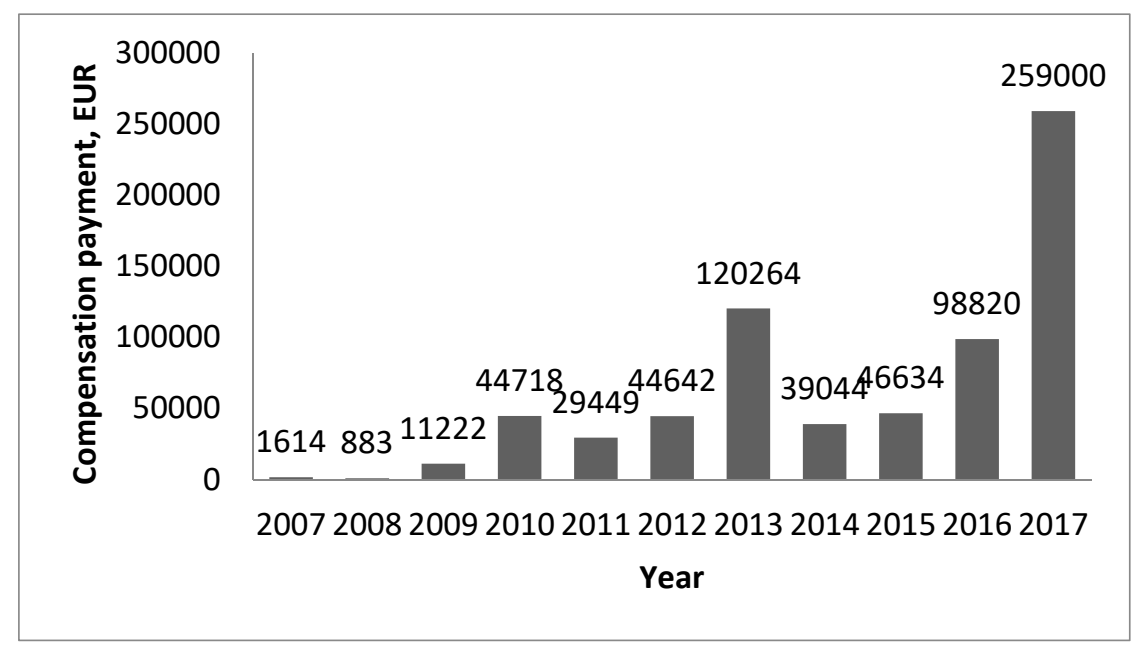

Figure 5. Compensation payments per year for damage to agricultural crops (source: Ministry of Environment of the Republic of Lithuania). 


\subsection{Habitat Selection by Free-Ranging European Bison}

The newly formed herd of European bison, which naturally split from the maternal group, entered into the territory in March 2016 and was tracked until the end of November. The largest home range area was in April (more than 700 ha), and it was larger in spring months compared to other months (Figure 6). The home range decreased from June to July, and it was smallest in July. It increased again from August to October.

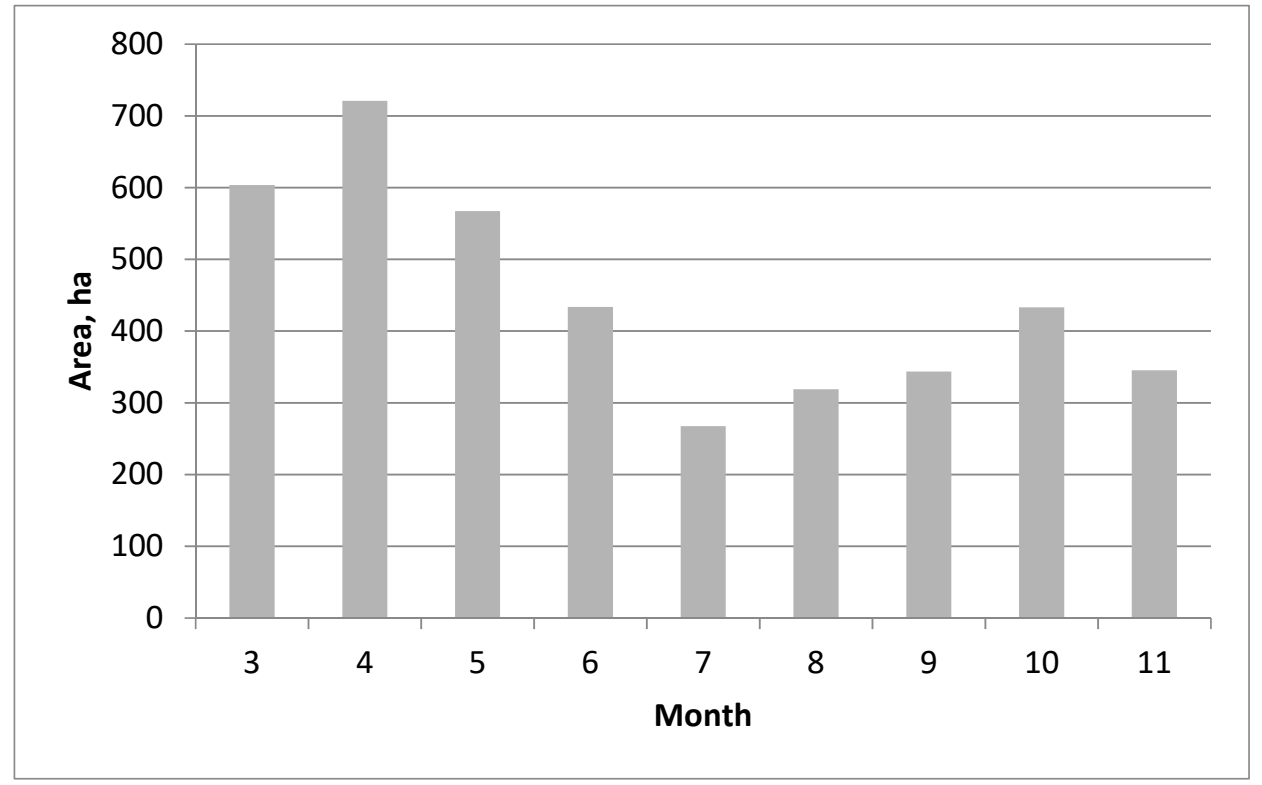

Figure 6. Home range of the free-ranging European bison herd.

The average daily walking distance of the herd was highest in March, when bison had just entered into the territory. In spring and early summer (April-June), the average walking distance slightly decreased. The lowest average walking distance was in summer and autumn (July-October). It increased again in November (Figure 7).

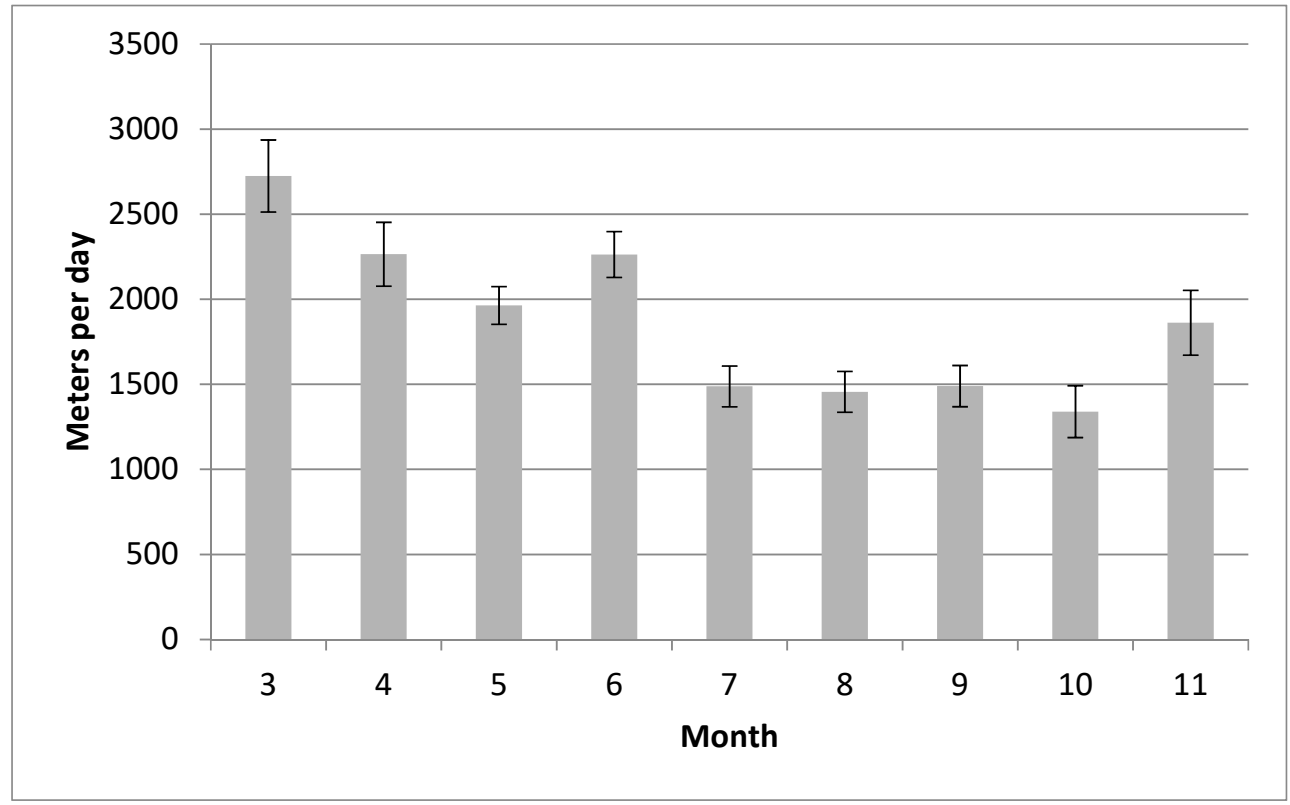

Figure 7. Average daily walking distance of the free-ranging European bison herd. 
European bison spent more time in the forest (Chi-square $p<0.001$ ) (Table 1 ) than in the agricultural land. This preference was significant during the daytime. At night, the bison preferences for forest or agricultural land were not significantly different (Table 1).

Table 1. Habitat selection of agricultural and forest land by the free-ranging bison herd.

\begin{tabular}{cccccc}
\hline Habitat Type & $\begin{array}{c}\text { Habitat } \\
\text { Proportion }\end{array}$ & $\begin{array}{c}\text { Habitat } \\
\text { Selection }\end{array}$ & Jacobs' Index & Chi-Square & $p$ \\
\hline Agricultural land & 63 & 39 & -0.457 & 24.212 & $<0.001$ \\
Forest & 37 & 61 & 0.457 & & \\
\hline Agricultural land day & 63 & 29 & -0.616 & 56.144 & $<0.001$ \\
Forest day & 37 & 71 & 0.616 & & \\
\hline Agricultural land night & 63 & 56 & -0.145 & 1.989 & 0.158 \\
Forest night & 37 & 44 & 0.145 & & \\
\hline
\end{tabular}

In the beginning (in March), the avoidance of the agricultural land was the lowest, but it increased up to May. The avoidance of the agricultural land decreased in summer, whereas it increased again in autumn (Figure 8). Meanwhile, in the agricultural land, bison preferred staying in crops of cereal and corn and avoided grasses (Table 2).

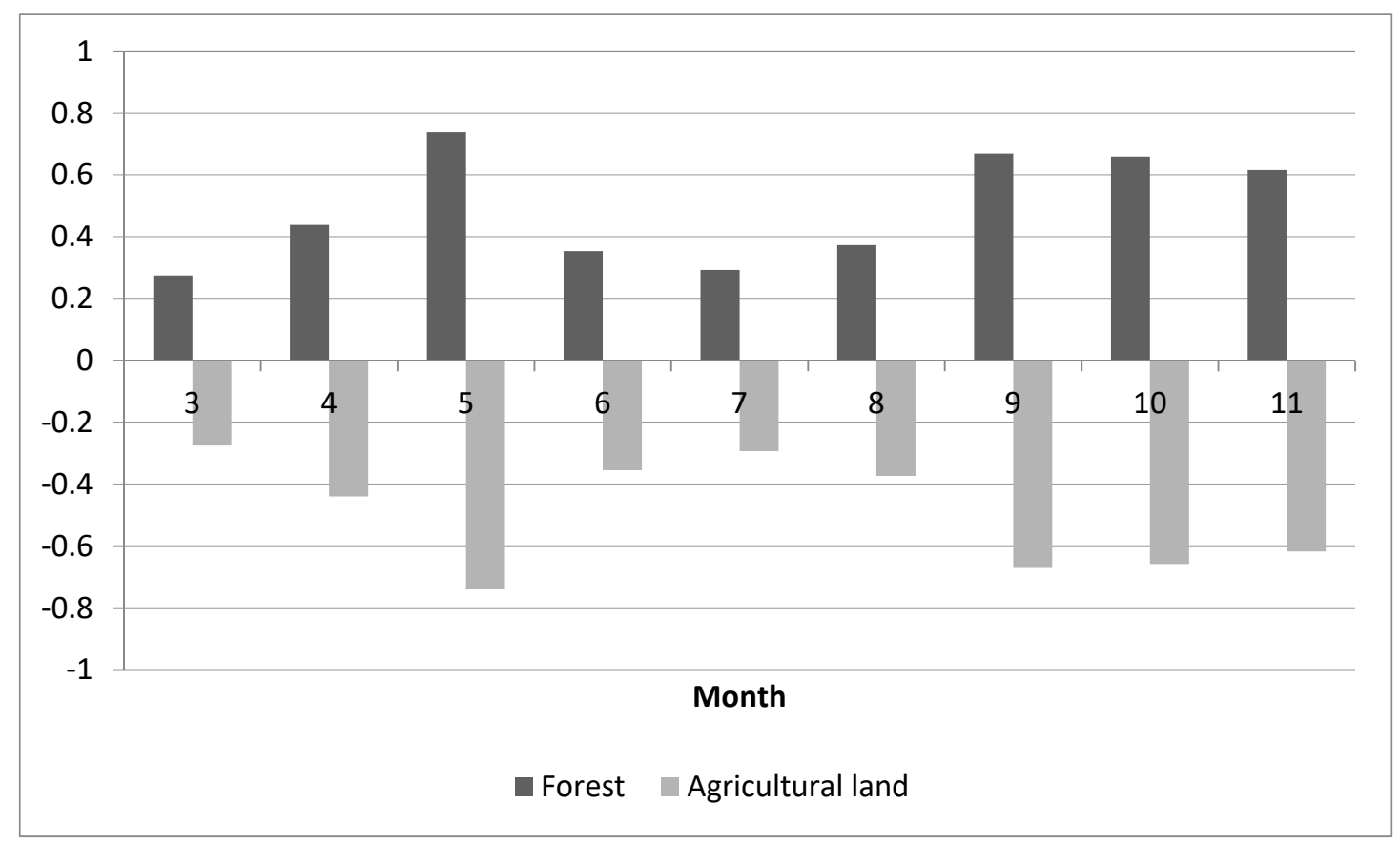

Figure 8. Jacobs' index of agricultural land and forest use in March-November by the free-ranging bison herd.

Table 2. Habitat selection of different crop types by the free-ranging bison herd.

\begin{tabular}{cccccc}
\hline Habitat Type & Habitat Proportion & Habitat Selection & Jacobs' Index & Chi-Square & $p$ \\
\hline Cereal & 59 & 64 & 0.118 & 7.872 & 0.045 \\
Corn & 20 & 22 & 0.089 & & \\
Grasses & 14 & 7 & -0.411 & & \\
Abandoned land & 7 & 7 & 0.003 & & \\
\hline
\end{tabular}


In the forest, European bison preferred clear-cut and small-leaved deciduous forests but avoided broad-leaved deciduous and coniferous forests (Table 3). When viewed according to the dominant tree species, the bison preferred aspen and grey alder but avoided ash and birch (Table 3).

Table 3. Habitat selection of forest dominant tree species by the free-ranging bison herd.

\begin{tabular}{cccccc}
\hline Habitat Type & Habitat Proportion & Habitat Selection & Jacobs' Index & Chi-Square & $p$ \\
\hline Clear-cut & 3 & 8 & 0.513 & 16.991 & $<0.001$ \\
Coniferous & 8 & 5 & -0.251 & & \\
Broad-leaved & 22 & 11 & -0.393 & & \\
Small-leaved & 67 & 76 & 0.223 & & 0.002 \\
\hline Ash & 21 & 11 & -0.356 & 16.755 & \\
Birch & 27 & 19 & -0.230 & & \\
Black alder & 20 & 22 & 0.050 & & \\
Grey alder & 12 & 23 & 0.356 & & \\
Aspen & 6 & 9 & 0.215 & & \\
\hline
\end{tabular}

When viewed according to the stand age, the bison preferred open areas (clear cuts), stands of 30-40 years old, and those more than 100 years old. The bison avoided young (10-20 years old) and 50-80-year-old stands (Table 4).

Table 4. Habitat selection of stand age by the free-ranging bison herd.

\begin{tabular}{cccccc}
\hline Habitat Type & Habitat Proportion & Habitat Selection & Jacobs' Index & Chi-Square & $p$ \\
\hline Clear cuts & 3 & 8 & 0.513 & 65.097 & $<0.001$ \\
$10-20$ & 12 & 8 & -0.213 & & \\
$30-40$ & 12 & 26 & 0.429 & & \\
$50-60$ & 18 & 10 & -0.303 & & \\
$70-80$ & 33 & 11 & -0.608 & & \\
$90-100$ & 18 & 25 & 0.229 & & \\
$>100$ & 4 & 12 & 0.485 & & \\
\hline
\end{tabular}

Habitat selection according to site humidity was insignificant (Chi-square $p=0.510$ ), but the bison slightly more often ranged in dry and moist habitats (Table 5).

Table 5. Habitat selection of sites of different humidity by the free-ranging bison herd.

\begin{tabular}{cccccc}
\hline Habitat Type & Habitat Proportion & Habitat Selection & Jacobs' Index & Chi-Square & $p$ \\
\hline Dry & 6 & 8 & 0.126 & 2.315 & 0.510 \\
Moist & 65 & 69 & 0.082 & & \\
Wet & 25 & 20 & -0.124 & & \\
Peat & 4 & 3 & -0.081 & & \\
\hline
\end{tabular}

\section{Discussion}

It has been discussed whether the European bison is a forest-dwelling or open habitat species. During the reintroduction process, European bison managed to live as a forest specialist despite its evolutionary background, dental morphology, neonatal behavior, diet, and microhabitat selection being characteristic of a grazing species of open, grass-rich habitats. A combination of increasing replacement of open steppe by forest cover after the last postglacial period and increasing human pressure forced the bison into forests as a refuge habitat $[9,25]$. The studies of the European bison show the complex importance of both habitats, open and forests [21,26,27]. In Židlov (Czech Republic) as well as in our study, the bison herd preferred forested habitats [18] during the daytime and more open lands at night. This finding supports an assumption that the European bison tends to be a forest specialist in 
Central Europe [28]. Other studies have indicated that European bison prefer open habitats [1,9,26,29]. The night and daytime differences in the selection of forest or agricultural land support the hypothesis that bison habitats are determined by disturbance (human and predators) avoidance rather than habitat preference [18]. Studies have shown the importance of landscape and habitat for large ungulate species [10,30]. Being large ruminating species, the European bison can tolerate food of lower energetic quality [31]. Ruminants are characterized by cycles of successive foraging and ruminating-resting bouts. The activity pattern of ruminants is consequently characterized by which habitats are selected at the within-home-range scale [32,33]. Commonly, ruminating species use shorter safe periods for collecting food in open habitats and ruminate during more risky time periods.

In the mosaic landscape, European bison spent more time in the forest (especially during the daytime). On the other hand, in summer and at night, the bison did not avoid agricultural land. In accordance with the "threat avoidance hypothesis" by Drucker and Bocherens [34], the bison use the forest under predation risk. In autumn and during the daytime, the bison tended to concentrate in forested areas. European bison living in anthropogenic landscapes (as in Lithuania) feed mostly on agricultural crops [7,20], which might explain their lower avoidance of agricultural land due to disturbance by farmers using machinery.

Our study indicated that European bison preferred open clear-cut and small-leaved deciduous forests but avoided broad-leaved deciduous and coniferous forests. Deciduous forests are the most suitable habitats for the European bison. In Białowieża forest, the bison mainly forage in fresh and moist deciduous forests, followed by mixed coniferous forests [21,29,35-37]. Forest complexes with mosaic-like forest types are the most favorable. Other studies have suggested that European bison also forage in habitats where coniferous forests predominate [38]. Brandtberg and Dabelsteen [39] reported that the reintroduced bison preferred coniferous forest stands during the growing season on a Danish island. Krasińska et al. [21] found that the main habitats of the bison in Białowieża forest consist of fresh and moist deciduous forests and mixed coniferous forests. The selection of habitats varied with the season. Deciduous forests were preferred in spring, mixed coniferous forests in summer, and deciduous forests together with mixed deciduous forests in autumn.

In our study, the bison preferred young plantations and stands of 30-40 or more than 100 years old. The bison avoided 10-20- and 50-80-year-old stands. A study in Białowieża forest reported that European bison inhabited ranges that included open areas, such as mown meadows, deforested feeding glades covered with grass, and clear cuts [40]. Open areas provide the bison with more food than the forest herb layer, and food is more easily available [41,42]. Krasińska and Krasiński [40] found that the bison rarely visited 10-20-year-old stands in the Białowieża forest. The bison preferred tree stands older than 20 years [21].

The decreased home range and average daily walking distance in summer were probably associated with the bison feeding in agricultural lands. Just after entering the new territory, the bison ranged over the territory; thus, the home range and average walking distance was largest. In autumn, the home range increased, probably due to the decreased food supply. In Židlov, Červeny et al. [18] found that the bison herd used the smallest territory in June and the largest territory in April. A strong seasonal pattern of bison movement was also found in the free-ranging Białowieża bison population [32].

A survey of attitudes in the region showed that three main factors explain the acceptance of the bison: Respondent concerns about their income, sustainability of agricultural practice, and attractiveness of the locality with respect to child safety and the value of real estate [43]. Unless farmers in the case of crop damage were fully compensated by the state, more than $2 / 3$ of respondents reported that their expenses for crop protection increased [43]. Due to fencing of fields to protect the crop, resources in the fragmented landscape became even more limited. This forced the bison to cross the roads more often and increase the risk of traffic accidents. In 2017-2018, the herd managed to cross the road border in the south and occupy two neighboring fragments in the mosaic of forest and agricultural fields. 
Usually, very dense populations spread into new territories as they exceed the maximal carrying capacity of the current territory [29]. For example, in Lithuania, the Red deer started dispersal when their population exceeded the density of 16-17 individuals per 1000 ha of forest [44]. Our observations showed that the key factor determining the dispersal of European bison is the size of the herd rather than the density. European bison most often create groups of 20 or fewer individuals in a forested territory. By contrast, small groups dominate in more open landscapes, although groups of $21-40$ individuals are also rather common [29].

The bison population in Lithuania is trapped by natural and human-made borders: River Nevėžis in the west and the Via Baltica highway in the east. In the north and the south, it borders urbanized territories. Long-term observations proved that these borders are rarely crossed, mainly by males, and they function as isolating factors. The bison formed the largest herd in the south of the territory. Not surprisingly, it split; a daughter herd dispersed into bison-free territory and subsequently appeared in the area of the current study. Such behavior shows that the bison herd is able to cross isolating borders and to move within the landscape with temporal stays in suboptimal habitats.

Due to human neighborhoods and high road density, the herds remain more concentrated, unsplit, and contain more individuals. Because of the larger herd size, the resource consumption is also higher. Consequently, in a fragmented landscape with limited resources, the dangerous crossing of roads and other borders increases even more. A proper management plan of the European bison population should be developed in such territories. A possible solution could be measures that split large herds of European bison and decrease the concentration of individuals by moving them into new territories.

\section{Conclusions}

Free-ranging European bison living sedentarily have formed six groups in the mosaic landscape of central Lithuania over a territory of 57 thousand ha. An extreme increase in the population has caused significant damage to agriculture crops.

The home range of the European bison herd studied herein was largest in spring, decreased in summer, and increased again in autumn, and this was associated with feeding and the food supply in agricultural lands.

In the mosaic fragmented landscape, European bison spent more time in the forest, especially during the daytime. In summer time and at night, the bison did not avoid agricultural land.

European bison preferred clear-cut, small-leaved deciduous (aspen, grey alder) forests of middle and mature age, but they avoided broad-leaved deciduous (ash), coniferous, and young forests.

To mitigate the negative agricultural effects of the growing European bison population, a proper management plan incorporating measures that split the herds and move animals into new territories is necessary.

Author Contributions: V.M., E.B., and G.B. conceived and designed the experiments; A.K. and K.Š. performed the experiments; K.S.., V.M., and A.K. analyzed the data; E.B., K.J., and G.B. contributed materials; V.M., A.K., and G.B. wrote the paper.

Funding: Kalev Jõgiste acknowledges the institutional research funding IUT21-4 of the Estonian Ministry of Education and Research.

Acknowledgments: We thank the anonymous reviewers for their valuable comments.

Conflicts of Interest: The authors declare no conflict of interest.

\section{References}

1. Pucek, Z.; Belousova, I.P.; Krasińska, M.; Krasiński, Z.A.; Olech, W. European Bison. Status Survey and Conservation Action Plan; IUCN/SSC Bison Specialist Group; IUCN: Gland, Switzerland, 2004; p. 54, ISBN 2-8317-0762-5.

2. Krasinski, Z.A. Dynamics and structure of the European bison in the Bialowieza Primeval Forest. Acta Theriol. 1978, 23, 13-48. [CrossRef] 
3. Perzanowski, K.; Olech, W.; Kozak, H. Constraints for re-establishing a meta-population of the European bison in Ukraine. Biol. Conserv. 2004, 120, 345-353. [CrossRef]

4. Decker, S.E.; Bath, A.J.; Simms, A.; Lindner, U.; Reisinger, E. The Return of the King or Bringing Snails to the Garden? The Human Dimensions of a Proposed Restoration of European Bison (Bison bonasus) in Germany. Res. Ecol. 2010, 18, 41-51. [CrossRef]

5. Mysterud, A.; Barton, K.A.; Jędrzejewska, B.; Krasinski, Z.A.; Niedzialkowska, M.; Kamler, J.F.; Yoccoz, N.G.; Stenseth, N.C. Population ecology and conservation of endangered megafauna: The case of European bison in Bialowieza Primeval Forest, Poland. Anim. Concerv. 2007, 10, 77-87. [CrossRef]

6. Matson, P.A.; Parton, W.J.; Power, A.G.; Swift, M.J. Agricultural intensification and ecosystem properties. Science 1997, 277, 504-509. [CrossRef]

7. Balčiauskas, L. European bison (Bison bonasus) in Lithuania: Status and possibilities of range extension. Acta Zool. Litu. 1999, 3, 3-18. [CrossRef]

8. Gordon, J.I. What is the future of wild, large herbivores in human-modified agricultural landscapes? Wildl. Biol. 2009, 15, 1-9. [CrossRef]

9. Kerley, G.I.H.; Kowalczyk, R.; Cromsigt, J.P.G.M. Conservation implications of the refugee species concept and the European bison: King of the forest or refugee in a marginal habitat? Ecography 2012, 35, 519-529. [CrossRef]

10. Hofman-Kaminska, E.; Kowalczyl, R. Farm Crops Depredation by European Bison (Bison bonasus) in the Vicinity of Forest Habitats in Northeastern Poland. Environ. Manag. 2012, 50, 530-541. [CrossRef] [PubMed]

11. Gill, R.M.A. A review of damage by mammals in north temperate forests: 3. Impact on trees and forests. Forestry 1992, 65, 363-388. [CrossRef]

12. Marozas, V.; Pètelis, K.; Brazaitis, G.; Baranauskaite, J. Early Changes of Ground Vegetation in Fallow Deer Enclosure. Balt. For. 2009, 15, 268-272.

13. Belova, $\mathrm{O}$. The impact of herbivorous mammals on woody vegetation in the different stages of forest succession. Balt. For. 2012, 18, 100-110.

14. Brazaitis, G.; Pètelis, K.; Žalkauskas, R.; Belova, O.; Danusevičius, D.; Marozas, V.; Narauskaitè, G. Landscape effect for the Cervidaes Cervidae in human-dominated fragmented forests. Eur. J. For. Res. 2014, 133, 857-869. [CrossRef]

15. Goswami, V.R.; Medhi, K.; Nichols, J.D.; Oli, M.K. Mechanistic understanding of human-wildlife conflict through a novel application of dynamic occupancy models. Conserv. Biol. 2015, 29, 1100-1110. [CrossRef]

16. van de Vlasakker, J. Rewilding Europe Bison Rewilding Plan 2014-2024; Rewilding Europe: Nijmegen, The Netherlands, 2014; p. 68, ISBN 978-90-822514-0-1.

17. European Bison (Bison bonasus L.) Protection Plan. Available online: https://e-seimas.lrs.lt/portal/legalAct/lt/ TAD/b3f90932605411e5b316b7e07d98304b/sMcpebTRCw (accessed on 5 April 2019). (In Lithuanian).

18. Červený, J.; Ježek, M.; Holá, M.; Zikmund, M.; Kušta, T.; Hanzal, V.; Kropil, R. Daily activity rhythm and habitat use of the semi-free European bison herd during the growing season. For. J. 2014, 60, 199-204. [CrossRef]

19. Kibiša, A.; Marozas, V.; Talijūnas, D.; Papšys, R.; Sabalinkienè, G.; Šimkevičius, K. Impact of Free-Ranging European Bison to Ecosystems in Fragmented Landscape, Lithuania. Balk. J. Wildl. Res. 2017, 4, 18-25. [CrossRef]

20. Balčiauskas, L.; Kazlauskas, M. Forty years after reintroduction in a suboptimal landscape: Public attitudes towards European bison. Eur. J. Wildl. Res. 2014, 60, 155-158. [CrossRef]

21. Krasińska, M.; Cabon-Raczyńska, K.; Krasiński, Z.A. Strategy of habitat utilisation by European bison in the Białowieża Forest. Acta Theriol. 1987, 32, 147-202. [CrossRef]

22. Krasińska, M.; Krasiński, Z.A.; Bunevich, A.N. Factors affecting the variability in home range size and distribution in the Polish and Belarussian parts of the Białowieża Forest. Acta Theriol. 2000, 45, 321-334. [CrossRef]

23. Boitani, L.; Fuller, T. Research Techniques in Animal Ecology; Columbia University Press: New York, NY, USA, 2000; p. 464, ISBN 978-0231113410.

24. Jacobs, J. Quantitative measurement of food selection. Oecologia 1974, 14, 413-417. [CrossRef] [PubMed]

25. Mendoza, M.; Palmqvist, P. Hypsodonty in ungulates: An adaptation for grass consumption or for foraging in open habitat? J. Zool. 2008, 274, 134-142. [CrossRef] 
26. Daleszczyk, K.; Krasińska, M.; Krasiński, Z.A.; Bunevich, A.N. Habitat structure, climatic factors, and habitat use by European bison (Bison bonasus) in Polish and Belarusian parts of the Bialowieza Forest, Poland. Can. J. Zool. 2007, 85, 26-272. [CrossRef]

27. Kowalczyk, R. European bison-king of the forest, or meadows and river valleys? In European Bison Conservation in the Biatowieża Forest Threats and Prospects of the Population Development, 2nd ed.; Kowalczyk, R., Lawreszuk, D., Wójcik, J.M., Eds.; Mammal Research Institute, Polish Academy of Sciences: Białowieża, Poland, 2010; pp. 123-134, ISBN 13 978-3642365546.

28. Verkaar, E.L.C.; Beeke, M.; Hanekamp, E.; Nijman, I.J.; Lenstra, J.A. Maternal and paternal lineages in interbreeding bovine species. Is wisent a hybrid species? Mol. Biol. Evol. 2004, 21, 1165-1170. [CrossRef] [PubMed]

29. Krasinska, M.; Krasinski, Z.A. European Bison, a Nature Monograph; Mammal Research institute, Polish Academy of Science: Bialowieza, Poland, 2007; p. 221, ISBN 978-83-907521-8-1.

30. Denny, C.K.; Stenhouse, G.B.; Nielsen, S.E. Scales of selection and perception: Landscape heterogeneity of an important food resource influences habitat use by a large omnivore. Wildl. Biol. 2018, 2018. [CrossRef]

31. Van Soest, P.J. Nutritional Ecology of the Ruminant, 2nd ed.; Cornell University Press: Ithaca, NY, USA, 1994; p. 488, ISBN 080142772X.

32. Kowalczyk, R.; Krasińska, M.; Kamiński, T.; Górny, M.; Struś, P.; Hofman-Kamińska, E.; Krasiński, Z.A. Movements of European bison (Bison bonasus) beyond the Białowieza Forest (NE Poland): Range expansion or partial migrations? Acta Theriol. 2013, 58, 391-401. [CrossRef]

33. Marchand, P.; Garel, M.; Bourgoin, G.; Dubray, D.; Maillard, D.; Loison, A. Coupling scale-specific habitat selection and activity reveals sex-specific food/cover trade-offs in a large herbivore. Anim. Behav. 2015, 102, 169-187. [CrossRef]

34. Drucker, D.G.; Bocherens, H. Carbon stable isotopes of mammal bones as tracers of canopy development and habitat use in temperate and boreal contexts. In Forest Canopies: Forest Production, Ecosystem Health and Climate Conditions; Creighton, J.D., Roney, P.J., Eds.; Nova Science Publishers: Hauppauge, NY, USA, 2009; pp. 103-109, ISBN 978-1-60741-457-5.

35. Dzięciołowski, R.M. Ecological niches of five big ungulates in Forest Tract. Folia Forestalia Polonica Ser. A For. 1991, 33, 56-70.

36. Krasiński, Z.A.; Krasińska, M. Free ranging European bison in Borecka Forest. Acta Theriol. 1992, 37, $301-317$. [CrossRef]

37. Kuemmerle, T.; Radeloff, V.C.; Perzanowski, K.; Kozlo, P.; Sipko, T.; Khoyetskyy, P.; Bashta, A.T.; Chikurova, E.; Parnikoxa, I.; Baskin, L.; et al. Predicting potential European bison habitat across its former range. Ecol. Appl. 2011, 21, 830-843. [CrossRef] [PubMed]

38. Krasiński, Z.A.; Krasińska, M.; Leniec, H. The European bison in the Knyszyn Forest. Parki. Nar. Rez. Przyr. 1994, 13, 107-114, (In Polish with English Summary).

39. Brandtberg, N.H.; Dabelsteen, T. Habitat selection of two European bison (Bison bonasus) on the Danish island Bornholm. Eur. Bison Conserv. Newsl. 2013, 6, 73-80.

40. Krasińska, M.; Krasiński, Z.A. Composition, group size and spatial distribution of European bison bulls in Białowieża Forest. Acta Theriol. 1995, 40, 1-21. [CrossRef]

41. Korochkina, L.N.; Bunevich, A.N. Znachenie kormovykh polei v pitanii kopytnykh Belovezhskoi Pushchi. Zapovedniki Belarussi. Issledovaniya 1980, 4, 109-116.

42. Kazmin, V.D.; Smirnov, K.A. Zimnee pitanie, kormovye resursy i troficheskoe vozdeistvie zubra na lesnye fitocenozy Tsentral'nogo Kavkaza. Byulleten' Moskovskogo Obshchestva Ispytatelei Prirody Otdel Biologicheskii 1992, 97, 26-35.

43. Balčiauskas, L.; Kazlauskas, M.; Balčiauskienè, L. European bison: Changes in species acceptance following plans for translocation. Eur. J. Wildl. Res. 2017, 63, 4. [CrossRef]

44. Padaiga, V. Biological Fundamentals of the Game Management; Ziburys: Vilnius, Lithuania, 1996; 212p, ISBN 9986524091. (In Lithuanian with English Abstract)

(C) 2019 by the authors. Licensee MDPI, Basel, Switzerland. This article is an open access article distributed under the terms and conditions of the Creative Commons Attribution (CC BY) license (http://creativecommons.org/licenses/by/4.0/). 